\title{
Formation of Information and Communication Competence of Future Teachers
}

\author{
https://doi.org/10.3991/ijet.v14i19.10990
}

\author{
Elena G. Matviyevskaya ${ }^{(\varpi)}$, Olga G. Tavstukha \\ Orenburg State Pedagogical University, Orenburg, Russia \\ elena.g.matviyevskayalgmail.com \\ Olga V. Galustyan \\ Southern Federal University, Rostov-on-Don, Russia \\ Petr A. Ignatov, Darya V. Miroshnikova \\ Orenburg State Pedagogical University, Orenburg, Russia
}

\begin{abstract}
This article introduces the problem of formation of ICT competence of future teachers. It discusses the process of educational informatization which relates to the ability of all participants of educational process to use modern information and communication technologies. The paper deals with the pedagogical potential of ICT, pedagogical methods, ICT means, pedagogical capabilities of ICT
\end{abstract}

Keywords - ICT competence, students, future teachers, didactic tools, pedagogical capabilities

\section{Introduction}

Modern education cannot be mentioned apart from the processes of economic, technical, cultural and social development. At the end of the 20th century there emerged a phenomenon of ICT means within the educational process. It represents the interaction of teachers and pupils, while all the parts of the learning process are implemented using Internet technologies or other means of interactivity $[1,5,6,19]$.

The main direction of the development of modern education system is introduction of modern information and communication technologies into a wide educational practice. The use of information and communication technologies (ICT) plays a huge role in the training of future teachers.

Modern information technologies are becoming one of the most important tools for school modernization. They facilitate the work of teachers and educators, make it possible to reduce the classroom burden on pupils, to diversify forms and ways of teaching to organize the learning process taking into account pupil's personal characteristics, and also to track the specific results of education.

One of the most important competencies of future teachers is not only ability for self-development, self-education, but also teacher's readiness for pedagogical activity 
in the conditions of informatization of education. Ability of teacher to use tools of information and information technology in order to solve professional problems becomes one of the components of his / her professional competence $[2,7,18]$.

One of the results of the process of educational informatization should be ability of all participants to use modern information and communication technologies within the educational process in order to work with information. All the participants of the educational process have to find the necessary data, to organize, to process, to analyze and to evaluate information, as well as to produce and to disseminate information in accordance to their goals.

\section{Methodology}

According to the modern pedagogical literature [1, 3, 13, 22] term "ICT competence" is used to determine the level of professional activity of a teacher in the field of ICT use.

Researches $[4,10,15,30]$ consider that ICT competence of a specialist is the ability of a specialist to solve educational and professional tasks using information and communication technologies. ICT competence of a teacher is a personal quality of a teacher, which is manifested in his / her readiness and ability to use information and communication technologies in his / her subject activity independently.

The process of ICT competence formation of a future teacher should obtain a developing character. Thus, the formation of ICT competence is the process of transition to a state where a future teacher, becomes able to find, to understand, to evaluate and to apply information in various forms in order to solve personal, professional, social or global problems.

It should be noted that modern ICT education is based on the use of the following elements:

- Informational transfer environments. Examples include informational networks and educational platforms.

- Methods of information exchange, depending on the technical environment.

Modern ICT education has a lot of advantages:

- Reduced costs on education

- Reduced time on education

- Students themselves can plan themselves their time, place and duration of the lessons

- Convenience for groups to study

- Improved quality of education due the use of modern technologies

Professional development of future specialists in modern conditions cannot be imagined without the active application the information and communication technologies (ICT), which have great pedagogical potential.

$[8,11,25,27]$ highlight the importance of information and communication competence of schoolteachers, who carry out their professional activities in the context of 
widespread introduction of information and communication technologies into the school educational space. The future of education depends on that how pedagogical staff is trained, how "free" they apply the means of information and communication technologies within the educational process.

Meanwhile, success of informatization and computerization of educational process as a whole depends on the information and computer competence of specialists in the field of education to a great extent. Teachers who are able to teach children the basic subjects of the school curriculum qualitatively, should apply new information technologies, and shape their information and computer culture. These specialists should also be well versed in children psychology, have a good command of teaching methods and be experts in the field of information technology.

Such teachers should possess the following knowledge and skills:

- To know the possibilities computer for training and development

- To master the methods of using a computer in organizing training of disciplines

- To use computer for organizing evaluation and self-control of pupils mastering the studied material

- To be able to combine computer and traditional learning technologies;

- To use new information technologies in order to organize pupil' creative activities in the classroom [28, 31, 34].

ICT have its own specifics in pedagogical university, because they act not only as an object of study, but also as a tool for subject and pedagogical activity, and as a means of educational and methodological support of educational process at school.

The formation of ICT competence of future teachers involves mastering of didactic properties of ICT tools.

Many researchers $[12,14,17]$ emphasize that the didactic properties of ICT tools can perform all educational functions (educational, teaching and developing) effectively.

We include to the didactic properties of ICT tools such qualities as communication and information retrieval activities, mobility, interactivity, objectivity and impartiality of information, obtaining more information, modeling, etc.

These properties allow ICT to ensure the implementation of an individual trajectory of professional development of the student:

- Adaptability of educational material (depending on the individual activities of the student);

- Multi-termination (simultaneous work of group of users)

- Interactive dialogue (interaction of technical means of learning and the student, imitating a certain degree of natural communication)

- Constant control of individual work of the student during an extracurricular time

ICT allows not only to issue information but also to make its presentation more rational, easy to understand. Various methods of providing educational information are used in this case:

- Simultaneous viewing of several fragments of educational material 
- Output of text information on monitors in different modes (reading, markup, Web pages, etc.)

- Reflection of the roles (values) of the educational material and the hierarchical links between them (the viewing tree)

- Navigation on the educational material

- Interactive presentation of educational material [9, 20,33].

It should be noted that graphical visualization of the ICT training information (visual representation on the screen of constituent parts, process, models,) is a powerful factor in activating cognitive activity.

The main capabilities of ICT applications of their graphic demonstration are:

- Monochrome, toning, full-color graphics

- Static, animation, sprite-representation of illustrations

- Direct inclusion in the educational process of information images of the surrounding world

- Visual representation of the object, its constituent parts

- The graphic interpretation of the studied regularity of the process

Demonstration capabilities of ICT can expand and strengthen the impact on the ways of audio presentation of the studied material. They include speech, music, demonstration commentary, sounds, technological signals, etc.

Complex presentation of the content of the educational material with the help of multimedia technologies (graphics, animation, video and audio support), threedimensional graphics, virtual reality technology makes it more accessible for understanding.

Programs based on multimedia technologies are considered as a multicomponent information environment, allowing to combine text, sound, video, graphic and animation within computer system. As a result, several sensory organs of audio and video information are immediately affected, that significantly improves the accuracy and strength of memorization of the studied material. Multimedia demonstrations with the use of three-dimensional (3D) graphics provide possibility of creating complete illusion of three-dimensional, holographic image of objects or processes being studied. They are becoming widespread increasingly.

ICT provide opportunities for individualization and differentiation of training. Maximum possible individualization and differentiation of the learning process is achievable when computer technologies and educational technologies are used. ICT provide a variety of educational process, which will give the students the ways to choose his / her trajectory of professional development and the individual rate of mastering knowledge, taking into account his / her physical, personal and other characteristics.

Opportunities to develop skills of group work, its organization, decision-making are realized with the help of software for working groups, communication, projection and multi-terminal equipment. These opportunities form the ability to initial organizational skills. 
Possibilities of ICT, which are used to consolidate knowledge are very important for the achievement of pedagogical goals. They are implemented in the teaching due to such methods as matching fragments of familiar and new material; "Running ahead"; reminder ("sending back") for a better understanding of the connection with the studied material; performing tasks with the "trainer" [27, 32, 35].

Such methods significantly reduce training time, increasing the strength and longevity of knowledge.

\section{Materials and Methods}

Educational tasks should be solved in order to achieve such educational goals:

- Rapid adaptation of learning process to the specific features

- Progress of skills in searching and making optimal decisions in non-standard situations

- Working with large volumes of information, search, systematization, transformation, storage, etc.

- Acquaintance with the systems and methods of multimedia presentation of information

- Formation of skills to use automated systems

It is important to emphasize that solution of these problems ensures design and implementation of individual trajectories of the students within their educational process $[16,22,29]$.

ICT perform informative, demonstration, training, communicative, instrumental functions within the educational process of university.

Informative function means that students can take advantage of the information resources (electronic dictionaries, databases, catalogs, etc.) in order to increase the efficiency of transferring and assimilation of educational information in the most convenient form for them.

Demonstration function provides structuring and illustrative representation of educational material, allows shifting the focus of the informative channel towards improving the quality and visibility of educational information significantly.

Training function of ICT is implemented in the training simulators which are directed to the development of certain skills and abilities, maintenance and restoration of them at the required level.

Communicative function of ICT meets the requirements of logical needs of the learning process between teaching ICT system and the users. Users themselves develop their communicative abilities.

Instrumental functions of ICT are automating of calculation, graphic, design and other tasks of training.

Such functions as diagnostic, organizational, regulating, motivational, and function of partner support of activities (information, professional, technical, etc.) are related to the functions which are delegated by teacher for the teaching ICT system. 
Diagnostic function provides constant and sustained feedback of the learning process, for example, checking correctness of certain results of the student and exhibiting his / her results of intermediate or final evaluation.

Organizational function helps the teacher to organize work of the students according to the pre-planned algorithm of the training ICT system.

Regulatory function relates to the possibility of setting up training programs for different levels of training.

Motivational function provides constant motivational regulation of training to improve the effectiveness of educational work.

Educators single out teaching (didactic), developing, educational and management tasks of ICT mean. They are presented in Table 1.

Table 1. Tasks of ICT Means

\begin{tabular}{|c|c|c|c|}
\hline Teaching (didactic) & Developing & Educational & Management \\
\hline $\begin{array}{l}\text { Presentation of educa- } \\
\text { tional information }\end{array}$ & $\begin{array}{l}\text { Development of infor- } \\
\text { mation culture }\end{array}$ & $\begin{array}{l}\text { Formation of adequate self- } \\
\text { esteem }\end{array}$ & $\begin{array}{l}\text { Organization of access } \\
\text { to information sources }\end{array}$ \\
\hline Practical training & $\begin{array}{l}\text { Development of skills in } \\
\text { research and creative } \\
\text { activity }\end{array}$ & $\begin{array}{l}\text { Education of independence, } \\
\text { habits of counting on one's } \\
\text { own strengths and opportu- } \\
\text { nities }\end{array}$ & $\begin{array}{l}\text { Use of various forms of } \\
\text { guidance for independ- } \\
\text { ent work of students }\end{array}$ \\
\hline $\begin{array}{l}\text { Instrumental and } \\
\text { partner support of the } \\
\text { teacher }\end{array}$ & $\begin{array}{l}\text { Development of figura- } \\
\text { tive thinking }\end{array}$ & $\begin{array}{l}\text { Formation of a positive } \\
\text { attitude towards learning }\end{array}$ & $\begin{array}{l}\text { Organization of feed- } \\
\text { back }\end{array}$ \\
\hline $\begin{array}{l}\text { Individualization and } \\
\text { differentiation of } \\
\text { education }\end{array}$ & Aesthetic development & $\begin{array}{l}\text { Educating self-reliance and } \\
\text { willingness to compete }\end{array}$ & $\begin{array}{l}\text { Pedagogical Diagnos- } \\
\text { tics }\end{array}$ \\
\hline $\begin{array}{l}\text { Activation of cognitive } \\
\text { activity }\end{array}$ & $\begin{array}{l}\text { Development of the } \\
\text { ability to convey infor- } \\
\text { mation presented in } \\
\text { various forms }\end{array}$ & $\begin{array}{l}\text { Education of the understand- } \\
\text { ing of the need for continu- } \\
\text { ous self-improvement }\end{array}$ & $\begin{array}{l}\text { Creating an open educa- } \\
\text { tion system that pro- } \\
\text { vides training }\end{array}$ \\
\hline
\end{tabular}

A computer acts as an irreplaceable assistant and partner support tool for a teacher. It acts as personal secretary, an analyst, a consultant, etc. The above list of functions and tasks are both assigned to ICT which determines the components of the ICT pedagogical potential such as ICT means, pedagogical methods and methods of their application, pedagogical capabilities of ICT.

ICT are more flexible and mobile as they obtain ability to organize large amounts of information, to provide easy access to it, its transfer and replication, that is, the ability to organize information support. There is no need to reproduce it in all training workplaces, which means that it is easier to update and monitor, because the training information can be located on servers and in remote access mode. Process of obtaining educational information becomes more dynamic and comfortable.

Quick search of information with the help of ICT tools such as hypertext, hypermedia, bookmarks, automated pointers, keyword search, full-text search, etc., creation of samples, queries, and reports speed up the independent work of pupils significant- 
ly. Presentations in a multimedia form of unique information materials (drawings, manuscripts, video fragments, sound recordings, etc.) allow to get a first-hand look at what humanity has accumulated in history.

Information and resource learning opportunities increase the amount of access to educational information to previously unthinkable limits. At the same time, teachers and students have the opportunity to make an extensive use of e-mail, electronic conferences and various Internet resources within traditional full-time education. Modern communication technologies allow to individualize and activate educational process even within the framework of group information intervention.

Methods of the traditional educational system can be realized with the help of the opportunities of communication technologies. Thus, lectures contain material, the perception of which is not required, can arise in electronic form, display on a local network, at Internet or an electronic conference. Lecture notes can be supplemented with the collections of articles, additional materials which are addressed to the specific students. Training can be realized with such technologies as ICQ, e-mail, that provide communication of teacher and pupil in individual form [17, 21].

Teachers and pupils can use electronic libraries, where they can find any information source quickly, visit Internet forum and discuss any topic of interest with other visitors, etc. Using ICT tools (searching engines, educational sites, mailing programs, etc.) allow teachers and pupils to share information, to collaborate with other pupils, to publish their ideas or comments, to participate in problem-solving and discussion.

Internet supports with text, graphics and multimedia pages. It is no longer a passive resource, but it is an environment that stimulates activity and independence of students, resourcefulness and initiative from the point view of educational opportunities.

The above description of pedagogical potential of ICT is far from exhaustive, mass application of ICT is just beginning. We can conclude that the full-scale introduction of these technologies promises revolutionary changes in education. Thus, pedagogical capabilities of ICT within the formation of information and communication competence (ICT) of future teachers are enormous and play an increasingly important role $[23,24,26]$.

\section{Results of the Study of Formation of ICT Competence of Future Teachers}

The study was conducted at Orenburg State Pedagogical University and Southern Federal University (Russian Federation).

The study was conducted at two universities (Orenburg State Pedagogical University and Southern Federal University) in 2017-2018. 188 students participated in the study. Respondents were from 19 to 21 years of age. Experimental group consisted of 93 future teachers. Control group included 95 future teachers.

Students of the control group studied the use of ICT in their future professional activities within the discipline "Informatics". Students of the experimental group attended additional training courses "Information Technologies in Education", "Fundamentals of Mathematical Information Processing", "Practicum on Electronic and Comput- 
er Office", "Statistical Processing of the Results of Pedagogical Research", "Modern Means of Assessing the Learning Outcomes", "Interactive Forms of Learning".

We conducted testing which made it possible to determine the initial level of formation of the components of information and communication competence of the students of experimental and control groups at the initial stage of the experiment.

We identified 4 components (cognitive, strategic, technical, and evaluative) of information and communication competence.

Cognitive component means awareness of the need for independent information retrieval to solve professionally oriented tasks effectively.

Strategic component provides for the ability to determine strategy of collecting and processing information that is optimal for ergonomic and time-consuming information which is necessary for specific educational and life situations and tasks.

Technical component includes the ability to use information resources, technologies, tools, Internet services effectively, as well as the ability to create software products.

Evaluative component means the ability to assess the reliability of information sources and information itself.

The data obtained were summarized and converted to percentage. The empirical data were quantitatively processed and analyzed at a qualitative level. Dynamics of step-by-step development of ICT competence was established and the obtained data are revealed in Table 2 and Table 3.

Table 2. The results of the assessment of the level of ICT competence in the experimental and control groups before the experimental work

\begin{tabular}{|l|c|c|c|c|c|c|}
\hline \multirow{2}{*}{ ICT competence } & \multicolumn{3}{|c|}{ Experimental group } & \multicolumn{3}{c|}{ Control group } \\
\cline { 2 - 7 } & $\begin{array}{l}\text { Low } \\
\text { level \% }\end{array}$ & $\begin{array}{l}\text { Middle } \\
\text { level \% }\end{array}$ & High level \% & $\begin{array}{l}\text { Low } \\
\text { level \% }\end{array}$ & Middle level \% & High level \% \\
\hline Cognitive component & 51,2 & 34,9 & 13,9 & 50,0 & 36,4 & 13,6 \\
\hline Strategic component & 55,8 & 32,6 & 11,6 & 54,5 & 34,1 & 11,4 \\
\hline Technical component & 58,1 & 32,6 & 9,3 & 59,1 & 31,8 & 9,1 \\
\hline Evaluative component & 55,8 & 32,6 & 11,6 & 56,8 & 34,1 & 9,1 \\
\hline
\end{tabular}

Table 3. The results of the assessment of the level of ICT competence in the experimental and control groups after the experimental work

\begin{tabular}{|c|c|c|c|c|c|c|}
\hline \multirow{2}{*}{$\begin{array}{c}\text { ICT } \\
\text { competence }\end{array}$} & \multicolumn{3}{|c|}{ Experimental group } & \multicolumn{3}{|c|}{ Control group } \\
\hline & Low level \% & Middle level \% & High level \% & Low level \% & Middle level \% & High level \% \\
\hline Cognitive component & 39,5 & 34,9 & 25,6 & 22,7 & 36,4 & 40,9 \\
\hline Strategic component & 48,8 & 32,6 & 18,6 & 29,5 & 31,8 & 38,7 \\
\hline Technical component & 48,8 & 30,2 & 21,0 & 29,5 & 34,1 & 36,4 \\
\hline Evaluative component & 46,5 & 30,2 & 23,3 & 22,7 & 34,1 & 43,2 \\
\hline
\end{tabular}

Comparative analysis of the results of input and final diagnostics of the formation of ICT competence of teachers in the control and experimental groups showed a significant dynamic of the development of ICT competence in experimental groups, which indicates the effectiveness of the experimental work. 


\section{Conclusion}

Dynamic changes in the modern world dictate the need to find new approaches to the theory and practice of forming ICT competence in all areas of human activity and especially in formation of ICT competence of future teachers.

Informatization of education is declared as one of the priority directions of the state policy in the field of education. ICT plays a unique role in improving the quality of education. It simplifies the integration of the national education system into the world one and facilitates an access to international sources of information in the field of education, science and culture.

The need of formation of ICT of future teachers relates to the changing of structure of educational information interaction between teachers and pupils. This interaction becomes active, it uses educational information, which transfers the learning process from the level of "passive information consumption" to the level of "active information transformation".

It also relates to the changing structure of presentation of educational material and methodological support of the educational process, which leads to the choice of an individual "learning path", a student-centered mode of learning activities, independent presentation and extraction of knowledge, implementation of information activities and information interaction with an interactive source of educational information.

\section{Acknowledgement}

The authors express their gratitude to the students who participated in the study for their assistance that made the following research possible.

\section{$7 \quad$ References}

[1] Ardıç, Ö. (2019). ICT competence and needs of turkish EFL instructors: The role of gender, institution and experience. Eurasian Journal of Applied Linguistics, 5(1), 153-173. https://doi.org/10.32601/ejal.543791

[2] Arrosagaray, M., González-Peiteado, M., Pino-Juste, M., \& Rodríguez-López, B. (2019). A comparative study of Spanish adult students' attitudes to ICT in classroom, blended and distance language learning modes. Computers and Education, 134, 31-40. https://doi.org/ 10.1016/j.compedu.2019.01.016

[3] Bubnov, Y. A., Gaidar, K. M., Fedorov, V. A., Berezhnaya, I. F., \& Galustyan, O. V. (2018). Organization of the training process based on modular and rating technology at higher educational institution. Espacios, 39(25)

[4] Butz, N.T., Stupnisky, R.H. (2017). Improving student relatedness through an online discussion intervention: The application of self-determination theory in synchronous hybrid programs. Computers and Education, 114, 117-138. https://doi.org/10.1016/j.compedu. $\underline{2017.06 .006}$

[5] Da Silva, V., Omar, N. (2017). Model of measurement of meaningful learning in distance learning environments. Iberian Conference on Information Systems and Technologies, CISTI. https://doi.org/10.23919/cisti.2017.7975696 
[6] Eliasquevici, M.K., Rocha Seruffo, M.C.D., Resque, S.N.F. (2017). Persistence in distance education: A study case using Bayesian network to understand retention. International Journal of Distance Education Technologies, 15 (4), 61-78. https://doi.org/10.4018/ijdet. 2017100104

[7] Galustyan, O. V., Gaidar, K. M., Aleshina, S. A., Ksenofontova, A. N., \& Ledeneva, A. V. (2018). Development of group subjectivity of pupils within collaborative activities. TEM Journal, 7(4), 854-858. doi:10.18421/TEM74-25

[8] Galustyan, O. V. (2015). Digital Campus as Electronic Image of the University. Rupkatha Journal on Interdisciplinary Studies in Humanities, 7(3), 263-270. Retrieved from http://rupkatha.com/V7/n3/28_digital-campus.pdf

[9] Galustyan, O. V., Berezhnaya, I. F., \& Beloshitsky, A. V. (2017). Professional and career development of teachers. Sodobna Pedagogika/Journal of Contemporary Educational Studies, 68(4), 158-172.

[10] Galustyan, O. V. (2017). Some Methodological Aspects of the Evaluation of Students' Educational Achievements at University. (IJCRSEE) International Journal of Cognitive Research in Science, Engineering and Education, 5(1), 43-48. Retrieved from http://www.ijcrsee.com/index.php/ijcrsee/article/view/278 https://doi.org/10.5937/ijcrsee $\underline{1701043 \mathrm{~g}}$

[11] Gibbons-Kunka, B. (2017). Synchronous office hours in an asynchronous course: Making the connection. International Journal of Information and Communication Technology Education, 13 (4), 98-110. https://doi.org/10.4018/ijicte.2017100108

[12] Herrera, O. A., Lévano, M., \& Rojas-Mora, J. (2019). Evaluating achievement of competences through integration workshops: An approach with strategies supported by ICT. Paper presented at the Proceedings - International Conference of the Chilean Computer Science Society, SCCC,2018-November https://doi.org/10.1109/sccc.2018.8705267

[13] Humanante-Ramos, P., Solís-Mazón, M. E., Fernández-Acevedo, J., \& Silva-Castillo, J. (2019). The ICT competences of students entering university: An experience in the faculty of health sciences of a latin american university. [Las competencias TIC de los estudiantes que ingresan en la universidad: una experiencia en la Facultad de Ciencias de la Salud de una universidad latinoamericana] Educacion Medica, 20(3), 134-139. https://doi.org/10. 1016/j.edumed.2018.02.002

[14] Levano, M. A., Herrera, O. A., \& Venegas, G. A. (2019). Self-regulation to activate the use of ICT in context of training by competencies: Case study in competencies of collaborative work, knowledge and management of information. Paper presented at the Proceedings - International Conference of the Chilean Computer Science Society, SCCC, , 2018November https://doi.org/10.1109/sccc.2018.8705232

[15] Losilla, F. (2017). A web-based design and assessment tool for educational wireless networking projects. Computer Applications in Engineering Education, 25 (6), 992-1000. https://doi.org/10.1002/cae.21850

[16] Martínez-Serrano, M. C. (2019). Perception of the integration and use of information and communication technologies (ICT). study about teachers and students of primary education. [Percepción de la integración y uso de las tecnologías de la información y la Comunicación (TIC). Estudio de profesores y estudiantes de educación primaria] Informacion Tecnologica, 30(1), 237-245. https://doi.org/10.4067/s0718-07642019000100237

[17] Mirķe, E., Kašparová, E., \& Cakula, S. (2019). Adults' readiness for online learning in the Czech Republic and Latvia (digital competence as a result of ICT education policy and information society development strategy). Periodicals of Engineering and Natural Sciences, 7(1), 205-215. 
[18] Pikhart, M. (2019). Multilingual and intercultural competence for ICT: Accessing and assessing electronic information in the global world doi:10.1007/978-3-319-98678-4_28

[19] Ragusa, A.T., Crampton, A. (2017) Online learning: Cheap degrees or educational pluralization? British Journal of Educational Technology, 48 (6), 1208-1216. https://doi.org/10. $\underline{1111 / \text { bjet. } 12489}$

[20] Ramírez-Donoso, L., Rojas-Riethmuller, J.S., Pérez-Sanagustin, M., Neyem, A. (2017). Enhancing collaborative learning in higher education online courses through a mobile game app. Proceedings of the 2017 IEEE 21st International Conference on Computer Supported Cooperative Work in Design, CSCWD 2017. 103-108. https://doi.org/10.1109/ cscwd.2017.8066678

[21] Rana K.P.S., Kumar V., Mendiratta J. (2017). An educational laboratory virtual instrumentation suite assisted experiment for studying fundamentals of series resistance-inductancecapacitance circuit European Journal of Engineering Education, 42 (6), 1220-1239. https://doi.org/10.1080/03043797.2017.1284764

[22] Ribeiro, A.C.R., Sonego, A.H.S., Do Amaral, C.B., Torrezzan, C.A.W., Machado, L.R., Behar, P.A. (2017). Social interactions in distance education: Development of a digital educational material [Article@Interações Sociais na Educação a Distância: desenvolvimento de um material educacional digital]. Iberian Conference on Information Systems and Technologies, CISTI. https://doi.org/10.23919/cisti.2017.7975876

[23] Riese, E. (2017). Students' Experience and Use of Assessment in an Online Introductory Programming Course. Proceedings - 5th International Conference on Learning and Teaching in Computing and Engineering, LaTiCE 2017. 30-34. https://doi.org/10.1109/latice. $\underline{2017.13}$

[24] Ross, J., Sheail, P. (2017). The 'campus imaginary': online students' experience of the masters dissertation at a distance. Teaching in Higher Education, 22 (7), 839-854. https:// doi.org/10.1080/13562517.2017.1319809

[25] Sekendiz, B. (2017) Utilisation of formative peer-assessment in distance online education: a case study of a multi-model sport management unit. Interactive Learning Environments. 1-13. https://doi.org/10.1080/10494820.2017.1396229

[26] Serrano, D.P., Manzano-Soto, N., Martínez, M.J.V. (2017). Virtual professional internships as an employability strategy: The case of UNED (SPAIN). Revista Espanola de Orientacion y Psicopedagogia, 28 (2), 122-138. https://doi.org/10.5944/reop.vol.28.num.2. 2017.20124

[27] Sheail, P. (2017). The digital university and the shifting time-space of the campus. Learning, Media and Technology, 1-14. DOI: 10.1080/17439884.2017.1387139

[28] Sherry, M.B. (2017). How the Visual Rhetoric of Online Discussions Enables and Constrains Students' Participation. Journal of Adolescent and Adult Literacy, 61 (3), 299-310. https://doi.org/10.1002/jaal.683

[29] Sousa, M.J., González-Loureiro, M. (2017). Comparative study on skills needed by organizations and effectively developed in eLearning management courses. Universal Access in the Information Society, 16 (4), 877-888. https://doi.org/10.1007/s10209-016-0492-x

[30] Valiente, D., Payá, L., de Ávila, S. F., Ferrer, J. C., \& Reinoso, O. (2019). Analysing students' achievement in the learning of electronics supported by ICT resources. Electronics (Switzerland), 8(3) https://doi.org/10.3390/electronics8030264

[31] Villarreal J.L., Cordoba J. X. M., Castillo C. M. (2016). De la educacion contable internacional al desarrollo de competencias. Revista Espacios, 37(33), 5. Retrieved from http://revistaespacios.com/a16v37n33/16373305.html 
[32] Wella, Tjhin, V.U. (2017). Exploring effective learning resources affecting student behavior on distance education. Proceedings - 2017 10th International Conference on Human System Interactions, HSI 2017. 104-107. https://doi.org/10.1109/hsi.2017.8005007

[33] Yooyativong, T. (2019). Developing teacher's digital skills based on collaborative approach in using appropriate digital tools to enhance teaching activities. Paper presented at the 6th Global Wireless Summit, GWS 2018, 156-160. https://doi.org/10.1109/gws.2018. 8686614

[34] Zhang, Q., Brode, L., Cao, T., Thompson, J.E. (2017). Learning laboratory chemistry through electronic sensors, a microprocessor, and student enabling software: A preliminary demonstration. Journal of Chemical Education, 94 (10), 1562-1566. https://doi.org/10.10 21/acs.jchemed.7b00172

[35] Zur, E., Benaya, T. (2017). Computer science teacher training. 2017 16th International Conference on Information Technology Based Higher Education and Training, ITHET 2017. https://doi.org/10.1109/ithet.2017.8067797

\section{Authors}

Elena G. Matviyevskaya is a Professor of Department of Pedagogy of Higher School of Orenburg State Pedagogical University, Orenburg, Russia.

Olga G. Tavstukha is a Professor of Department of Pedagogy of Higher School of Orenburg State Pedagogical University, Orenburg, Russia

Olga V. Galustyan is a Professor of the Department of Education and Pedagogical Sciences of Southern Federal University, Rostov-on-Don, Russia.

Petr A. Ignatov is a Postgraduate of Department of Pedagogy of Higher School of Orenburg State Pedagogical University, Orenburg, Russia.

Darya V. Miroshnikova is a Postgraduate of Department of Pedagogy of Higher School of Orenburg State Pedagogical University, Orenburg, Russia.

Article submitted 2019-06-04. Resubmitted 2019-09-10. Final acceptance 2019-09-11. Final version published as submitted by the authors 